\title{
Factors Affecting the Age of Admission of Postmenopausal Women to an Osteoporosis Outpatient Clinic
}

\author{
Postmenopozal Dönemdeki Kadınların Osteoporoz Polikliniğine Başvuru \\ Yaşında Etkili Faktörler
}

\author{
Ferda Özdemir ${ }^{1}$, şenay Demir Yazıcı ${ }^{1}$, Derya Demirba g Kabayel ${ }^{1}$, Necdet Süt ${ }^{2}$ \\ 1Trakya Üniversitesi Tıp Fakültesi, Fiziksel Tıp ve Rehabilitasyon Anabilim Dalı, Edirne, Turkey \\ ${ }^{2}$ Trakya Üniversitesi Tıp Fakültesi, Biyoistatistik Anabilim Dalı, Edirne, Turkey
}

\begin{abstract}
Objective: In the present study, the factors that may potentially affect the age of admission of postmenopausal women to an osteoporosis (OP) outpatient clinic were evaluated.

Materials and Methods: Two hundred and twenty-six postmenopausal women admitted to our OP outpatient clinic were studied retrospectively. The level of education, occupation, age at menopause, duration of menopause, history of hormone replacement therapy (HRT), exercise routine, history of medication use that may cause secondary OP, and family history of OP were questioned. Lumbar spine and femur bone mineral density (BMD) measurements were performed by dual energy x-ray absorptiometry (DEXA). The data were analyzed by linear regression.

Results: The mean age of the patients was $58.8 \pm 8.7$ years (range, 37-82 years) and the mean age at menopause was $45.2 \pm 5.8$ years. Multiple backward stepwise linear regression was performed. When factors which could potentially affect the age of admission to OP outpatient clinic were included in the model, only 2 factors (age at menopause and duration of menopause) were shown to affect the age of admission. These two variables explained $98.9 \%$ of the variation (adjusted $\left.R^{2}\right)$ in admission age $(p<0.001)$.

Conclusion: The most important factors affecting the age of admission of postmenopausal women to the OP outpatient clinic were determined to be the age at menopause and the duration of menopause.
\end{abstract}

(Turk J Rheumatol 2010; 25: 72-6)

Key words: Osteoporosis, postmenopausal period, outpatient

Received: 09.07.2008

Accepted: 05.12.2008

\section{Özet}

Amaç: Bu çalıșmada, kadınların postmenopozal dönemde osteoporoz (OP) polikliniğine bașvuru yașında etkili olabilecek faktörler araștırıldı.

Yöntem ve Gereçler: Bu amaçla OP polikliniğimize bașvuran 226 postmenapozal kadın olgu retrospektif olarak incelendi. Tüm olguların eğitim durumları, meslekleri, menopoza girdikleri yaș, menopoz süresi, hormon replasman tedavisi (HRT) alıp almadığı, egzersiz alıșkanlığı, sekonder OP yapacak ilaç öyküsünün olup olmadığı ve ailedeki OP öyküsü sorgulandı. Kemik mineral yoğunluğu (KMY) değerlendirmeleri lomber omurga ve femurdan DEXA ile yapıldı. Veriler lineer regresyon analizi ile değerlendirildi.

Bulgular: Hastaların yass ortalaması 58.8 \pm 8.7 (37-82) olup, menopoz yas ortalamaları $45.2 \pm 5.8$ idi. Bașvuru yașını etkileyebileceği düșünülen faktörler çok değișkenli geriye dönük adımsal doğrusal regresyon modeline (Backward stepwise lineer regression analysis) konulduğunda yalnızca 2 etkenin (menopoz yașı ve süresi) bașvuru yașını etkilediği saptandı. Söz konusu iki değișkenin bașvuru yașındaki değișimin \%98.9'luk kısmını (Adjusted R2) açıkladığı bulundu. Regresyon modelinin $p$ değeri $<0.001$ olarak bulundu.

Sonuç: Sonuç olarak postmenopozal kadınlarda OP polikliniğine bașvuru yașını etkileyen en önemli faktörün; menopoz yașı ve süresinin olduğu görüldü..

(Turk J Rheumatol 2010; 25: 72-6)

Anahtar sözcükler: Osteoporoz, postmenopozal dönem, poliklinik

Alındığı Tarih: 09.07.2008

Kabul Tarihi: 05.12.2008 


\section{Introduction}

Osteoporosis (OP) is a systemic disease characterized by a reduction in bone mass and microarchitectural deterioration of bone tissue, leading to enhanced bone fragility and a consequent increase in fracture risk (1). OP, also termed "the silent epidemic disease," needs to be recognized in all aspects so that preventive measures can be taken and optimal treatment methods can be offered (2). It is known that genetic structure, socioeconomic status, lifestyle characteristics such as exercise, nutrition, smoking and alcohol consumption, the use of medications affecting bone structure (i.e., glucocorticoids, some diuretics, antacids, and hormone replacement therapy) have effects on bone mineral density (BMD) and have to be evaluated among the risk factors for OP (3-5).

Early diagnosis is as important as effective treatment in OP. The progression of disease can be halted and even substitution of the loss is possible by some simple interventions in early diagnosed patients $(2,6)$. For an early diagnosis, the patients need to be admitted to the OP outpatient clinics as early as possible.

Dual energy X-ray absorptiometry (DEXA) is the most widely used technique for the quantitative assessment of bone structure. DEXA is currently accepted as the gold standard for the determination of OP and fracture risk (7).

By raising awareness in society, it will be possible to diagnose and implement preventive measures earlier for the individuals at risk for OP. Believing that the age of admission to an OP outpatient clinic might be one of the criteria reflecting public awareness, we aimed to investigate the factors potentially affecting the age of admission to an OP outpatient clinic.

\section{Materials and Methods}

Two hundred and twenty-six postmenopausal women, admitted to our OP outpatient clinic within the Department of Physical Medicine and Rehabilitation, were retrospectively studied in this study. The study population consisted of women admitted to an outpatient clinic for BMD measurement and OP risk assessment for the first time. Women who had previously been examined for BMD, those who had been referred from other departments for OP, and men were excluded.

The level of education, occupation, age at menopause, duration of menopause (years), history of hormone replacement therapy (HRT), exercise routine, history of medication use that may cause secondary OP, family history of OP (diagnosis of OP or osteoporotic fractures) were questioned.

Lumbar spine (L2-4, L2, L3, and L4) and femur (femur neck and trochanter) BMD measurements were performed by DEXA. BMD results were expressed as $\mathrm{g} / \mathrm{cm}^{2}$.

The level of education was evaluated in 5 categories: 1 , no education; 2 , primary school; 3 , secondary school; 4 , high school; and 5, college or university degree.

Individuals who performed exercise equivalent to walking at a fast pace or jogging for at least 1 hour $\geq 3$ times a week were considered to perform regular exercise.
The Spearman correlation test was used to evaluate the relationship between BMD and age at the time of admission, age at menopause, and duration of menopause. Comparison of BMD according to fracture history, use of medications that may cause OP, exercise routine, HRT use, and family history of OP was performed by an independent samples t-test. Potential parameters which may affect the age of admission to the outpatient clinic were initially assessed by univariate linear regression analysis, and the significant parameters were further examined by multivariate backward stepwise linear regression analysis. Statistical analysis of the data was performed by the SPSS 11.0 program. P values $<0.05$ were considered statistically significant.

\section{Results}

The mean age of the 226 postmenopausal women was $58.8 \pm 8.7$ years (range, $37-82$ years). The mean age at menopause was $45.2 \pm 5.8$ years (range, $25-55$ years) and the mean duration of menopause was $13.8 \pm 9.7$ years (range, 1-43 years).

Among the study population, 126 (55.8\%) were housewives, $83(36.7 \%)$ were retired and $17(7.5 \%)$ were currently employed as workers. When the education level was considered, it was observed that $16(7.1 \%)$ were illiterate, $87(38.5 \%)$ were primary school graduates, 26 $(11.5 \%)$ were secondary school graduates, 35 (15.5\%) were high school graduates, and $62(27.4 \%)$ had a college or university degree.

Although BMD values measured at all sites were negatively correlated with the age and the duration of menopause of the patients $(p<0.05)$, the correlation was weak as ' $r<0.5$ ' (Table 1). There was no significant relationship between the age at menopause and BMD values ( $p>0.05$; Table 1).

The BMD values were compared in all subgroups:

A significant difference existed between occupation subgroups in terms of femur neck and L2 BMD values $(p<0.05)$. Currently employed workers had a significantly higher L2 BMD $\left(0.932 \pm 0.124 \mathrm{~g} / \mathrm{cm}^{2}\right)$ than housewives $\left(0.833 \pm 0.161 \mathrm{~g} / \mathrm{cm}^{2}\right)(p=0.035)$ and retired individuals had a significantly higher femur neck BMD $(0.787 \pm 0.179 \mathrm{~g} /$ $\left.\mathrm{cm}^{2}\right)$ than housewives $\left(0.725 \pm 0.148 \mathrm{~g} / \mathrm{cm}^{2} ; \mathrm{p}=0.022\right)$. Housewives had lower BMD at both sites. There was no significant difference between the occupation subgroups in terms of other BMD values ( $p>0.05)$.

Illiterate women had a significantly lower femur neck BMD $\left(0.660 \pm 0.100 \mathrm{~g} / \mathrm{cm}^{2}\right)$ than those with a college or university degree $\left(0.795 \pm 0.184 \mathrm{~g} / \mathrm{cm}^{2} ; \mathrm{p}=0.019\right)$. There was no significant difference between the education subgroups in other BMD values ( $p>0.05$ ).

There was a significant difference between the BMD values of patients with a fracture history at L2, L3, the femur neck, and the trochanter $(p<0.05)$. There was no significant difference between BMD values of individuals with or without previous use of medications which may cause OP $(p>0.05)$. The BMD values of patients who performed regular exercise were significantly higher than 


\begin{tabular}{lcccc}
\multicolumn{5}{l}{ Table 1. Correlation of BMD values with age, age at menopause, and duration of menopause } \\
\hline \multicolumn{1}{c}{ BMD measurement site } & & Age & Age at menopause & Duration of menopause \\
\hline L2-4 & $\mathrm{r}$ & -0.220 & 0.002 & -0.235 \\
& $\mathrm{p}$ & $0.001^{*}$ & 0.977 & $0.000^{*}$ \\
L2 & $\mathrm{r}$ & -0.293 & 0.029 & -0.311 \\
& $\mathrm{p}$ & $0.000^{*}$ & $0.000^{*}$ & -0.207 \\
L3 & $\mathrm{r}$ & -0.227 & -0.049 & $0.002^{*}$ \\
& $\mathrm{p}$ & $0.001^{*}$ & 0.466 & -0.218 \\
L4 & $\mathrm{r}$ & -0.191 & 0.027 & $0.001^{*}$ \\
& $\mathrm{p}$ & $0.004^{*}$ & 0.688 & -0.456 \\
Femur neck & $\mathrm{r}$ & -0.483 & 0.076 & $0.000^{*}$ \\
& $\mathrm{p}$ & $0.000^{*}$ & 0.255 & -0.275 \\
Trochanter & $\mathrm{r}$ & -0.307 & 0.036 & $0.000^{*}$
\end{tabular}

the values of patients who did not perform regular exercise at all sites $(p<0.05)$. No significant difference was noted between BMD values of patients with or without a history of HRT use ( $p>0.05)$. A significant difference was observed between BMD values of patients who did or did not have a family history of OP at all sites $(p<0.05)$. The mean BMD values according to subgroups and intergroup comparisons are presented in Table 2 .

Univariate regression analysis of potential factors which may affect the age of admission revealed that occupation, level of education, fracture history, exercise routine, HRT use, age at menopause, duration of menopause, L2-4 BMD, L2 BMD, L3 BMD, L4 BMD, femur neck $B M D$, and trochanter $B M D$ values were associated with the age at the time of admission $(p<0.05)$. However, use of medications that may cause OP and a family history of OP were not associated with the age at the time of admission to the OP outpatient clinic ( $p>0.05$; Table 3).

When potential factors which may affect the age of admission to the outpatient clinic were included in backward stepwise linear regression analysis, only two variables (age at menopause and menopause duration) were found to affect the age at the time of admission. These variables explained $98.9 \%$ of the variation (adjusted $R^{2}$ ) in admission age ( $p<0.001$; Table 3$)$.

\section{Discussion}

Given the increase in the elderly population, OP is currently one of the most important health problems (8). OP is the basic cause of bone fractures mostly observed in elderly individuals. As bone mass decrease, bones become more prone to fractures. Genetic factors, environmental factors, and lifestyle have a major impact on bone mass (9).

Believing that the age of admission to an OP outpatient clinic might be one of the criteria reflecting public awareness, we aimed to determine the factors potentially affecting the age of admission to an OP outpatient clinic. First, we evaluated whether there was a difference between BMD values of the subgroups formed according to the predetermined criteria. We noted that BMD values differed between the subgroups determined according to occupation, fracture history, exercise routine, and family history of the individuals. We considered that the features which have led to a difference in BMD values could affect the admission age. In univariate analysis, all of these criteria except family history had an effect on the age of admission. However, this finding was not observed in the multivariate model. The age at menopause and the duration of menopause appeared to be the major factors which affected admission to the OP outpatient clinic. Contrary to our expectations, personal history of fractures or family history of OP did not appear to be triggering factors for an earlier admission. Similarly, occupational differences or differences in exercise routine did not have the anticipated effect on admission to the OP outpatient clinic. Kavuncu et al. (10) have reported that family history of OP or related factors did not have a significant effect on predicting OP in women. In a study on the initial densitometric evaluation of 6160 postmenopausal women, Varenna et al. (11) reported that physical activity level was closely associated with educational level and had an impact on OP. In postmenopausal women, Yaraman et al. (12) reported that BMD values decreased by an increase in age and age at menopause, and the values were elevated in those who performed regular exercise.

In education subgroups, we observed a significant difference in only femur neck BMD values between illiterate individuals and individuals with a college or university degree. The difference noted in only one measurement site was not sufficient to conclude that the level of education provides a difference in terms of BMD. Although many studies evaluated the relationship between chronic diseases and education level, a few investigated the association between bone health and education level. Aksu et al. (13) noted that the increase in awareness about OP was positively correlated with the level of education, and the level of awareness was high in individuals with a high level of education. However, despite the observed association between the level of education and admission age in univariate analysis, the level of education was not found to affect admission age in the multivariate model in the present study. 


\begin{tabular}{|c|c|c|c|c|c|c|}
\hline \multirow[t]{2}{*}{ Parameter } & \multicolumn{6}{|c|}{ BMD* and inter-group comparisons } \\
\hline & L2-4 & L2 & L3 & L4 & Femur neck & Trochanter \\
\hline \multicolumn{7}{|c|}{ Fracture history } \\
\hline No $(n=180)$ & $0.866 \pm 0.15$ & $0.858 \pm 0.15$ & $0.878 \pm 0.16$ & $0.854 \pm 0.16$ & $0.762 \pm 0.16$ & $0.615 \pm 0.09$ \\
\hline Yes $(n=46)$ & $0.828 \pm 0.16$ & $0.813 \pm 0.17$ & $0.812 \pm 0.20$ & $0.839 \pm 0.18$ & $0.705 \pm 0.12$ & $0.570 \pm 0.11$ \\
\hline $\mathrm{p}$ & 0.054 & 0.007 & 0.020 & 0.332 & 0.015 & 0.012 \\
\hline \multicolumn{7}{|c|}{ Use of medications that may cause OP } \\
\hline No $(n=131)$ & $0.862 \pm 0.16$ & $0.855 \pm 0.16$ & $0.866 \pm 0.19$ & $0.855 \pm 0.18$ & $0.761 \pm 0.17$ & $0.604 \pm 0.09$ \\
\hline Yes $(n=95)$ & $0.852 \pm 0.14$ & $0.841 \pm 0.15$ & $0.863 \pm 0.14$ & $0.846 \pm 0.14$ & $0.737 \pm 0.14$ & $0.609 \pm 0.11$ \\
\hline $\mathrm{p}$ & 0.924 & 0.807 & 0.682 & 0.748 & 0.771 & 0.524 \\
\hline \multicolumn{7}{|c|}{ Regular exercise } \\
\hline No $(n=162)$ & $0.846 \pm 0.16$ & $0.838 \pm 0.16$ & $0.859 \pm 0.17$ & $0.839 \pm 0.18$ & $0.732 \pm 0.14$ & $0.596 \pm 0.10$ \\
\hline Yes $(n=64)$ & $0.887 \pm 0.12$ & $0.878 \pm 0.12$ & $0.880 \pm 0.16$ & $0.883 \pm 0.13$ & $0.797 \pm 0.19$ & $0.633 \pm 0.09$ \\
\hline $\mathrm{p}$ & 0.002 & 0.003 & 0.016 & 0.007 & 0.000 & 0.003 \\
\hline \multicolumn{7}{|l|}{ HRT use } \\
\hline No $(n=173)$ & $0.857 \pm 0.16$ & $0.848 \pm 0.16$ & $0.864 \pm 0.18$ & $0.849 \pm 0.18$ & $0.741 \pm 0.15$ & $0.602 \pm 0.11$ \\
\hline Yes $(n=53)$ & $0.859 \pm 0.11$ & $0.852 \pm 0.13$ & $0.869 \pm 0.12$ & $0.859 \pm 0.11$ & $0.782 \pm 0.19$ & $0.620 \pm 0.08$ \\
\hline $\mathrm{p}$ & 0.393 & 0.518 & 0.328 & 0.323 & 0.116 & 0.439 \\
\hline \multicolumn{7}{|c|}{ Family history of OP } \\
\hline No $(n=201)$ & $0.873 \pm 0.15$ & $0.865 \pm 0.15$ & $0.879 \pm 0.17$ & $0.864 \pm 0.17$ & $0.761 \pm 0.16$ & $0.614 \pm 0.10$ \\
\hline Yes $(n=25)$ & $0.738 \pm 0.09$ & $0.724 \pm 0.09$ & $0.750 \pm 0.10$ & $0.748 \pm 0.10$ & $0.666 \pm 0.12$ & $0.539 \pm 0.09$ \\
\hline $\mathrm{p}$ & 0.000 & 0.000 & 0.000 & 0.000 & 0.002 & 0.000 \\
\hline
\end{tabular}

Table 3. Results of univariate and multivariate regression analyses of factors potentially affecting admission age to the OP outpatient clinic

\begin{tabular}{|c|c|c|c|c|c|}
\hline & \multirow{2}{*}{$\begin{array}{l}\text { Variable types/ } \\
\text { categories }\end{array}$} & \multicolumn{2}{|c|}{ Univariate Model } & \multicolumn{2}{|c|}{ Multivariate Model } \\
\hline & & b* & $\mathbf{P}$ & $\mathbf{b}^{*}$ & $\mathbf{P}$ \\
\hline Occupation & $\begin{array}{l}\text { 0: unemployed } \\
\text { 1: employed }\end{array}$ & $-0,425$ & 0,000 & $-0,009$ & 0,402 \\
\hline Education level & $\begin{array}{l}0:<\text { college level } \\
1: \geq \text { college level }\end{array}$ & $-0,488$ & 0,000 & 0,009 & 0,418 \\
\hline Fracture history & $0:$ no, 1 : yes & 0.201 & 0.002 & 0,004 & 0.650 \\
\hline $\begin{array}{l}\text { Use of medications } \\
\text { that may cause O }\end{array}$ & $0:$ no, 1 : yes & 0.083 & 0.212 & - & - \\
\hline Regular exercise & $0:$ no, $1:$ yes & 0.160 & 0.016 & -0.005 & 0.552 \\
\hline Age at menopause & $\begin{array}{l}\text { Quantitative } \\
\text { variable }\end{array}$ & 0.159 & 0.017 & 0.667 & 0.000 \\
\hline Duration of menopause & $\begin{array}{l}\text { Quantitative } \\
\text { variable }\end{array}$ & 0.798 & 0.000 & 1.104 & 0.000 \\
\hline History of HRT & $0:$ no, $1:$ yes & -0.247 & 0.000 & 0.007 & 0.354 \\
\hline Family history of OP & $0:$ no, $1:$ yes & 0.040 & 0.545 & - & - \\
\hline L2-4 BMD & $\begin{array}{l}\text { Quantitative } \\
\text { variable }\end{array}$ & -0.216 & 0.001 & 0.021 & 0.565 \\
\hline L2 BMD & $\begin{array}{l}\text { Quantitative } \\
\text { variable }\end{array}$ & -0.268 & 0.000 & -0.017 & 0.499 \\
\hline L3 BMD & $\begin{array}{l}\text { Quantitative } \\
\text { variable }\end{array}$ & -0.202 & 0.002 & 0.002 & 0.899 \\
\hline L4 BMD & $\begin{array}{l}\text { Quantitative } \\
\text { variable }\end{array}$ & -0.183 & 0.006 & 0.001 & 0.942 \\
\hline Femur neck BMD & $\begin{array}{l}\text { Quantitative } \\
\text { variable }\end{array}$ & -0.392 & 0.000 & -0.012 & 0.264 \\
\hline Trochanter BMD & $\begin{array}{l}\text { Quantitative } \\
\text { variable }\end{array}$ & -0.356 & 0.000 & 0.004 & 0.722 \\
\hline
\end{tabular}


We did not detect any difference between BMD values of subgroups formed according to the use of HRT and to the use of medications which may cause OP. Type, duration, and doses of medication which might also have had an influence on our results were not evaluated in the study. This may be considered as a limitation. Horsman et al. (14) reported a dose-dependent effect of estrogen on postmenopausal bone loss. In addition, many studies reported the positive effects of HRT on BMD $(15,16)$. Baret-Canner et al. (17) showed that the BMD of individuals, who have used HRT, even for a very short period of time, was higher compared to those who have never used HRT.

Awareness of OP can also be evaluated by using questionnaires. There are previous studies in the literature on this topic (18-22). Juby and Davis (19) evaluated the level of knowledge of elderly individuals regarding OP. They reported that women had a greater knowledge about OP compared to men and also those with previous fractures and those who performed regular exercise also had a greater knowledge. Only the elderly were included in their study. We proposed an association between admission age to the OP outpatient clinic and awareness of OP, and examined the factors affecting the age of the patients at the time of admission. Therefore, our study population consisted of postmenopausal women from all age groups. In order to provide standardization, only female individuals were evaluated.

Giangregorio et al. (22) conducted a questionnairebased study on a group of health-care professionals concerning the risk factors of OP. They emphasized the importance of education of health care professionals who should refer the patients for early diagnosis and treatment of OP.

Awareness of osteoporotic patients was evaluated in a multi-center study in Turkey (21). Significant difference was noted in the awareness of subgroups formed according to the level of education, physical activity, body mass index, obesity, and smoking status. Moreover, awareness was significantly different in different regions of the country.

In conclusion, it was determined that the main factors leading our patients to admit to the OP outpatient clinic were the age at menopause and the duration of menopause.

\section{Conflict of Interest}

No conflict of interest is declared by authors.

\section{References}

1. NIH Consensus Development Panel on Osteoporosis Prevention, Diagnosis, and Therapy. Osteoporosis prevention, diagnosis, and therapy. JAMA 2001; 285: 785-95.

2. II. Ulusal Osteoporoz Kongresi Raporu. Osteoporoz Dünyasından 2005; 11: 133-6.

3. Sadler C, Huff M. African-American women: health beliefs, lifestyle, and osteoporosis. Orthop Nurs 2007; 26: 96-101.

4. Wolker Bone K, Dennison E, Cooper C. Epidemiology of osteoporosis. Rheum Dis Clin North Am 2001; 27: 1-18.
5. Gemalmaz A, Discigil G, Sensoy N, Basak O. Identifying osteoporosis in a primary care setting with quantitative ultrasound: relationship to anthropometric and lifestyle factors. J Bone Miner Metab 2007; 25: 184-92.

6. Prins $\mathrm{SH}$, Jurgensen $\mathrm{HL}$, Jurgensen LV, Hassager $\mathrm{C}$. The role of quantitative ultrasound in the assessment of bone: a review. Clin Physiol 1998; 18: 3-17.

7. Kanis JA, Delmas $P$, Burckhardt $P$, Cooper C, Torgerson D. Guidelines for diagnosis and management of osteoporosis. The European Foundation for Osteoporosis and Bone Disease. Osteoporos Int 1997; 7: 390-406.

8. Pande KC, de Takats $D$, Kanis JA, Edwards V, Slade $P_{\imath}$ McCloskey EV. Development of a Questionnaire to Asses Patient's Knowledge About Osteoporosis. Maturitas 2000; 37: 75-81.

9. Walker-Bone K, Dennison E, Cooper C. Epidemiology of osteoporosis. Rheum Dis Clin North Am 2001; 27: 1-18.

10. Kavuncu $H$, Elyas $H$, Akın $H$, Kavuncu V. Osteoporozda aile öyküsü ve cinsiyet faktörünün incelenmesi. İstanbul Üniversitesi İstanbul Tıp Fakültesi Dergisi 2000; 63.

11. Varenna M, Binelli L, Zucchi F, Ghiringhelli D, Gallazzi M, Sinigaglia L. Prevalence of osteoporosis by educational level in a cohort of postmenopausal women. Osteoporos Int 1999; 9: 236-41.

12. Yaraman N, Celik C, Karaoğlan B. Postmenopozal kadınlarda osteoporoz ile çok yönlü risk faktörlerinin değerlendirilmesi. Fiziksel Tıp Dergisi 2002; 5: 23-6.

13. Aksu A, Zinnuroğlu $M$, Karaoğlan $B$, Akın $S$, Kutsal $Y G$, Atalay F, ve ark. Osteoporoz, Eğitim Durumu ve Farkındalık Düzeyi Araștırma Sonuçları. Osteoporoz Dünyasından 2005; 11: $36-40$.

14. Horsman A, Jones $M$, Francis $R$, Nordin C. The effect of estrogen dose on postmenopausal bone loss. New Engl J Med 1983; 309: 1405-7.

15. Levine JP. Long-term estrogen and hormone replacement therapy for the prevention and treatment of osteoporosis. Curr Womens Health Rep 2003; 3: 181-6.

16. Burkman RT. Hormone replacement therapy. Minerva Ginecol 2003; 55: 107-16.

17. Barrett-Connor E, Wehren LE, Siris ES, Miller P, Chen YT, Abbott TA 3rd, et al. Recency and duration of postmenopausal hormone therapy: effects on bone mineral density and fracture risk in the National Osteoporosis Risk Assessment (NORA) study. Menopause 2003; 10: 412-9.

18. Górski R, Chmielewski D, Zgoda M. The evaluation of social awareness of osteoporosis, based on the aimed questionnaire. Ortop Traumatol Rehabil 2006; 8: 627-32.

19. Juby $A G$, Davis P. A prospective evaluation of the awareness, knowledge, risk factors and current treatment of osteoporosis in a cohort of elderly subjects. Osteoporos Int 2001; 12: 617-22.

20. Schulman JE, Williams S, Khera O, Sahba T, Michelson J, Fine $\mathrm{K}$. Effective osteoporosis education in the outpatient orthopaedic setting. J Bone Joint Surg Am 2007; 89: 301-6.

21. Kutsal YG, Atalay A, Arslan S, Bașaran A, Cantürk F, Cindaș $A$, et al. Awareness of osteoporotic patients. Osteoporos Int 2005; 16: 128-33.

22. Giangregorio L, Fisher $P$, Papaioannou A, Adachi JD. Osteoporosis knowledge and information needs in healthcare professionals caring for patients with fragility fractures. Orthop Nurs 2007; 26: 27-35. 